\title{
AMERICAN INFLUENCE AND REPRESENTATION IN JAPANESE MANGA AND ANIME-BNHA's All Might
}

\author{
Marica Orrù \\ Independent scholar
}

\section{ABSTRACT}

When talking about manga, we are typically referring to Japanese comics. The term is often mistaken and used interchangeably with the word anime, which contrarily to the written comics refers to the animated adaptations of Manga or to original animation products. Since 1970, Japanese Manga and Anime have experienced an unprecedented popularity, introducing an innovative way of telling stories and portraying reality eventually absorbed into our Western culture. This article examines the animated series adaptation of Kohei Horikoshi's Boku No Hero Akademia, paying particular attention to one of the main characters: All Might.

Keywords: manga, anime, BNHA, American culture, Japanese culture, adaptation.

When talking about manga in Western popular culture, we are typically referring to Japanese printed and digital comics. Outside Japan, the term is often mistaken and used interchangeably with the term anime, which instead refers to the animated adaptations of manga, as well as original animation products. Since the 1970s, Japanese manga and anime have experienced an unprecedented popularity abroad (Brenner 11), introducing an innovative way of telling stories and portraying reality eventually absorbed into Western culture.

Among the first to use the term manga is Katsushika Hokusai (1760-1849), a Japanese artist, engraver, and painter who coined the word to describe his collection of drawings, pictures and sketches (Shodt, "Manga! Manga!" 35). With time, collections like those created by Hokusai and their natural evolution into more complex stories have become a solid base for other forms of art and media, such as anime indeed. While it might be easy to assume that anime is the natural evolution of manga, this process was far from linear and it was not developed within the limitations of Japanese culture. In fact, right after Hokusai's death, Japanese history witnessed an event that took a heavy toll on the country's culture and artistic expression. After obtaining its long-craved independence in 1776, the government of the 
United States of America started a phase of expansion which-among its main goals-aimed at the annexation of the Southwest, pushed by a particular interest in the Pacific trade. In order to pursue this goal, in 1853 a representative of the government was sent to Japan with the task of establishing a commercial and political relationship. Yielding to the pressure, Japan had no choice but to open its ports and to begin trading with the United States, initiating a relationship whose strength would result in reciprocate indelible influence on both cultures. In fact, this period of continuous changes has been employed as the setting for historic narrations numerous times and has undoubtedly represented the start of a profound contamination of Western elements in the Japanese culture (Brenner 3).

\section{JAPAN AND THE USA: The ORIGINS OF A Mutual Contamination}

In such a political climate, Japan was bearing pressures from not only American but also European powers in search for new commercial deals. The Japanese government decided to take advantage of notions and innovations peculiar to the Western civilization to strengthen Japan rather than protecting its traditional culture. The period between the second half of the XIX century and the first years of the XX century provided to the Western world an extremely rich set of remarkable discoveries in both technological and scientific fields. Within a few decades, the world's first international exposition took place in London in 1851, the emancipation of slaves was proclaimed in the United States in 1863, Alexander Graham Bell invented the telephone in 1876, and just a couple of years later Edison refined the electric lamp. Meanwhile, Japan had just abolished the feudal system thanks to the so-called Meiji Restoration, the series of events which brought the governmental power back to the Emperor after two centuries of shōgun [military dictators] reign. The introduction of Western innovations in such a radically different society resulted in the creation of a tremendous gap between the lifestyle of the Japanese masses and the technological civilization pushed by the government. This phenomenon has been accurately explained by Dr. Raphael von Koeber, a German philosopher who spent eighteen years in Japan at the end of the XIX century:

Japan's attitude in adopting European culture was problematic in every aspect. The Japanese did not try to transplant the roots of the plant, but simply cut off eye catching flowers. A a result the people who brought the flowers were respected enormously, but the plants that could have produced such blossoms did not come to grow in our country. (Watsuji 72)

From being extremely grateful for the gifts Western people were bringing to their country, Japanese people started to suffer an intense inferiority complex, which led them to believe to be unable of being agents of their own modernization. This inferiority complex survived this transition period and remained still even when Japan became a major military power (Irokawa 51-68).

Furthermore, a new period of intense cultural contamination was represented by the post-World War II American occupation of Japan, which lasted - at least officially - until 1952. 
After the overwhelming defeat endured by Japanese people during the war, the country was characterized by a devastated landscape in which the only signs of civilization were the American soldiers patrolling in their jeeps. Even after the end of the occupation-thanks to the San Francisco treaty stipulated between the two countries-American soldiers remained on the Japanese islands taking advantage of a treaty's clause that allowed them to keep a series of military bases along the whole territory. Their presence in the cities and the image of those American men in uniform riding jeeps were assimilated in a drastically different way from local adults and children. From the adults' point of view, Americans were a constant reminder of their country's defeat, a symbol of loss and oppression; however, children often saw American soldiers as fascinating people driving extraordinary vehicles and dispensing free candies. With time, the charm radiated on children began to hit also the initially reluctant adults.

The jeep itself became the symbol of the American glamour almost immediately after the end of the war. The Japanese biggest economy driver was represented by the toys production industry, which began to take the American vehicle as a model for toy reproductions. The success of the toy grew frenziedly and unstoppable across the ocean. After Japanese children had bought and loved it, the little jeep spread also among American soldier in Japan who kept it on their real jeeps as a souvenir helping the toy to reach America itself. The diffusion of toys that represented or reproduced objects related to war and violence created a wave of nationwide protests in Japan around 1951, but despite the evident contribution of those toys (the jeep in particular) in idealistically transforming the oppressors in admirable allies, they were too loved by the public to be banned. Also, as Alt stated, "Thanks to toys, Japan could finally begin rebuilding it export trade. The only condition was that the products clearly be marked MADE IN OCCUPIED JAPAN" (12). At this point no past (and present) oppression, cruelty or injustice could stop Japan from being infected by the international idealization of American culture which still survives in the present days (Alt 12-24).

In this time frame Tezuka Osamu (1928-1989) - one of the founding fathers of Japanese manga and anime and often referred to as manga no kamisana [God of manga]-embodied more than anyone the American influence in the Japanese arts of the XIX century. Inspired by popular American cartoons and encouraged by the newly conquered Japanese freedom after the long period of censorship and oppression due to World War II, Tezuka Osamu started a massive production of manga. By then, the term manga had completely changed its meaning from the Hokusai's conception of it. Prior to Japan's modernization, the term was used by Hokusai and others as a collective word, referring to a certain quantity of drawings with different illustrations and styles not necessarily connected by a common narrative. By the time Tezuka Osamu began his artistic career, the term had already evolved to indicate a specific style of drawing and telling stories and was about to evolve again, gaining explicit references from modern novels and cinema (Berndt 3-6).

Tezuka focused his work on a specific genre that has been called shonen up to the present. The word shōnen literally means "boy" or "youth" as originally the target of this genre 
was supposed to be mainly composed by young boys. Angela Drummond-Mathews explained that "Shonen manga typically follow the pattern of the heroic journey" (70), a concept elaborated by Joseph Campbell who studied the rites of passage that every hero has to deal with. Drawing on Campbell's work, Drummond-Mathews stated that

The hero leaves a place of familiarity to cross a threshold or barrier into a world of unfamiliarity. [He/she] must suffer trials, usually with assistance from a helper figure or a shaman. The hero will likely suffer some kind of nadir and atonement that will be followed by gaining a boon, wisdom, power, or a magical item that can be brought back upon the return to benefit the world (70).

The post-war manga proposed by Tezuka Osamu also had a whole new printed format: the comic book were small, cheap, and characterized by red covers, often referred to as simply akahon [red] or "red books." Tezuka's signature and his innovative way of creating Japanese illustration can still be seen in the typical representation of the characters' big eyes, which do not resemble Japanese physical appearance but rather evoke all-American characters such as Betty Boop and Mickey Mouse. Although he was profoundly influenced by the American culture, the artist was successful in creating his own style: a mix between Japanese tradition and American innovation, that marked the start of a long history of Japanese manga and anime production. Tezuka was very fascinated by the cinematic techniques used by the animation works produced The Walt Disney Company and the Fleisher Studios, which led him to try and bring some of their methods into the manga productions. For example, he applied motion picture technology by drawing sketches while impersonating the role of a film director. He drew as if he was watching the scene through the camera lenses. He was also convinced that the manga format could be used to tell every kind of stories: from comedy to drama and from adventure to horror. For this reason, he was one of the first to conceive longer story arcs with deeper character developments (Brenner 6-7).

His early work is still celebrated as a masterpiece. For example, Astro Boy (1952), which was later adapted into an animated series, attracted the attention of Walt Disney who complimented Tezuka for his work and suggested a collaboration in the future. Similarly, Jungle Emperor (1954) gained growing popularity in the USA with the title of Kimba the Lion. When it was released in 1994, Disney's The Lion King sparked a controversy around the evident resemblances between the latest Disney cinematic masterpiece and Tezuka's work. A member of the Disney staff who collaborated on the project even referred to the film protagonist calling him "Kimba" but Roger Allers, one of the directors - who was later interviewed about the issuedeclared that there was no connection between the two animated works. Moreover, it was in the public domain that Disney and Tezuka had worked together in the past, as some of Disney's graphic designers helped Tezuka's team with the use of color techniques for the animation of Kimba the Lion. In the early phases of the scripting of the animated series, the protagonist was even called "Simba" and only later adapted to "Kimba" to avoid a problem with the 
legal registration of the commercial brand, since the word "Simba" means "lion" in African Swahili. Disney avoided the problem by excluding the protagonist's name from the title.

The end of the controversy came with an open letter to the Disney Studio sent by Machiko Satonaka, a well-known Japanese animator, in which she asked for a few lines regarding the origin of the story to be included in the movie. Satonaka's intentions were the ones of many Japanese artists and Tezuka's admirers; however, the Japanese mainstream public was too passionate about the Disney work to be involved in the controversy, that found its end soon after Stonaka's letter.

As the market of manga and anime kept growing, it also evolved giving space for more genres and categories to emerge. For example, people who fell in love with manga when they were kids struggled to find new stories that could satisfy their need of an adult representation, so the gekiga [dramatic pictures] genre was born. This new type of manga introduced adult themes into the narration, including morally gray characters, violence, sex, and criminality (Brenner 8). In the 1970s, the world of manga and anime also witnessed the birth of the shojo [girl] genre targeted mainly at the female universe, with female creators and main characters producing a sort of female version of the shonen.

Eventually, manga and anime reached worldwide popularity and pervasiveness even in the West, phenomenon that has been growing ever since. Through the years, the range of categories has become richer than ever, with thousands of titles and genres being available and new stories in the making. For example, a relevant further evolution is the emergence of digital comics, that is to say comics adapted for the digital format or even born specifically to be read on the screen. Even if the manga market is still strictly supported by the selling of physical copies, the digital formats have highly encouraged the diffusion of titles around the world.

Unsurprisingly, the US mainstream public has been extremely fascinated with Japanese manga and anime. In the 1990s, the US comics industry experienced a big manga boom, when editors finally conceded to the necessity of a massive translation work and distribution of Japanese titles which, until that moment, were spread only by committed fans. In short time, the Western public became familiar with the changes brought by manga and anime, including reading from right to left and watching anime episodes with English subtitles, thus sealing the mutual contamination that has begun over a century earlier (Brenner 11).

Such a cross-contamination has continued up to the present day and it has kept on bringing some American elements (and sometimes stereotypes) into very popular manga and anime. This paper will examine Kohei Horikoshi's Boku No Hero Academia, paying particular attention to one of the main characters: All Might.

\section{BOKU NO HERO ACADEMIA}

Boku No Hero Academia (commonly known to the international audience as My Hero Academia) is a shōnen manga created by Kohei Horikoshi and published for the first time by the Japanese 
publisher Shueisha in 2014. As mentioned above, the intended audience for this kind of manga is represented by young boys and-as coming-of-age stories - the narrations often feature a set of treated themes such as family, friendship, sacrifice, and commitment in order to better themselves and/or achieve a particular goal. Boku No Hero Academia which is still being published after 31 tankōbon [volumes], presents all of these features and has almost immediately met the public's favor, becoming one of the most popular shōnen manga of our time.

Two years after the first publication, Bones Studio adapted the print comic into an anime series, of which five seasons have been aired originally by JNN. Since 2016, the title has become a transmedia franchise. Besides the anime, three video games have been developed by Dimps and published by Bandai Namco Entertainment (the first one for Nintendo 3DS in 2016, followed by two adaptations for Play Station 4, Nintendo Switch, Xbox One and PC in 2018 and 2020), a mobile game has been released in several English-speaking countries for iPhone and Android in 2021, two spin-off manga were published, four Original Anime Videos (OAV) and three theatrical films were released between 2016 and 2021. For the purpose of this study, the anime series (2016-present) - which is very faithful to the comic version both at a visual and at a narrative level-will serve as the basis for the analysis.

Kohei Horikoshi's work is set in a fictional world where eighty percent of the population has a superpower referred to as a "Quirk." The main character is Midoriya Izuku, a young boy about to start high school who decides to attempt the entrance test for one of the most famous hero academies in all of Japan: The UA High School. The main existential problem Midoriya must face is that he is one of the few of his generation to be born without any Quirk. Despite this impediment, he believes that his willingness to help those in need and his wide knowledge on superheroes and their powers will give him a chance to enter the academy. Right when it is time to sign up for the test, Midoriya is involved in an accident instigated by a villain character. A mud monster kidnaps one of his current classmates, Bakugou, and he decides to intervene to save his friend's life. Bakugou and Midoriya are eventually saved by All Might, not only the Number One Hero in Japan and the protagonist's biggest idol, but also the one who inspired Midoriya to become a hero despite lacking a Quirk. After observing the bravery and the selflessness shown by the young boy, All Might decides to reveal his most precious secret to him: All Might's Quirk, a power based on super strength and speed called One for All, which is hereditary and can be transferred even to someone who does not have any special ability. Nearly at the end of his career, All Might is looking for the next possessor of One for All, who could take his place. After seeing Midoriya's heroic stance while facing the mud monster to save his friend, he is convinced that the young boy would be the ideal successor. It is from this moment on that Midoriya will start his training to enter the UA Hero Academy and begin his journey to become the next Number One Hero.

Referring to the American influence in Japanese manga and anime mentioned at the outset of this article, the character of All Might represents the embodiment of several American stereotypes. The hero's connection with the American culture is clear since one of his first 
appearance in Episode 1 (min. 19:10). After saving Bakugou and Midoriya from the mug monster, All Might traps the creature into two plastic bottles in order to bring him to the police. While showing the way in which he took advantage of the monster's Quirk to beat him, All Might is depicted as surrounded by red, white, and blue stripes sprinkled with stars in a quite clear reference to the American flag. Also, the scene evokes the style of old Coca Cola advertising images, where smiling men and women held the bottles to show to the public what kind of drink made them that happy (Fig. 1).

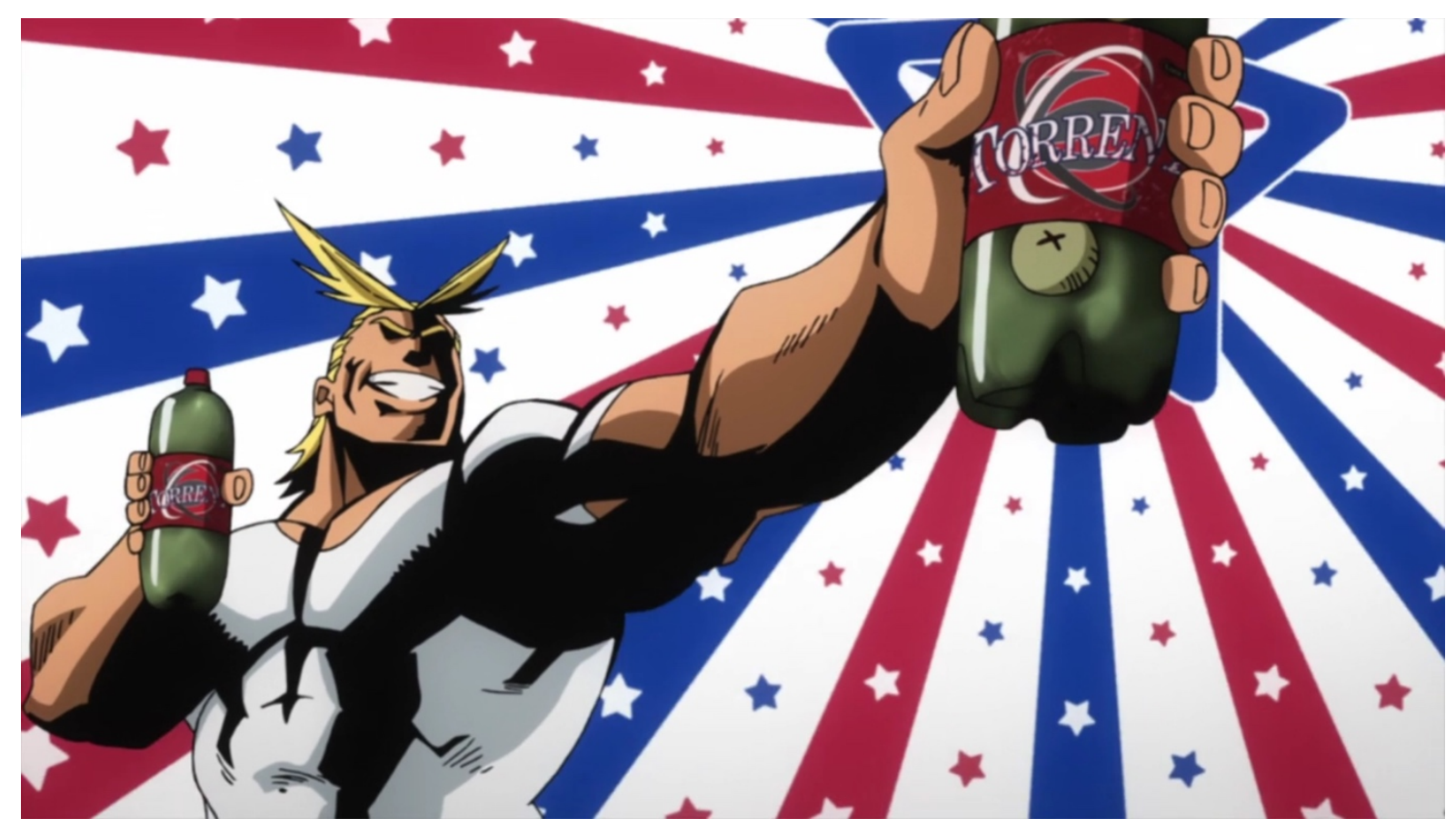

Figure 6 All Might showing to Midoriya the bottled up mud monster (Season 1, Episode 1).

In addition, the Number One Hero often uses American expressions (ex. "Yes," "Repeat after me," "Nonsense!" etc.) and his hero suit is embedded with the colors of the American flag, making him look to an extent like a Japanese anime version of Captain America.

\section{All Might AND CAPTAin America}

All Might and Captain America have a lot in common indeed, starting from the physical appearance. The two of them are blonde, big, muscular men wearing a fitted superhero uniform colored in blue, red and white. While interpreting their heroic-self, the two men behind the mask also assume similar positions and make comparable moves (Fig. 2). For example, All Might's legendary attack is the "Smash": a strong fist in which he gathers all of his strength. Even if Captain America does not use a specific name for his attacks, he frequently knocks down his enemies with his fists especially in the early phases of his history as a superhero, when he is still not in possess of the round shield that will become his personal weapon. 

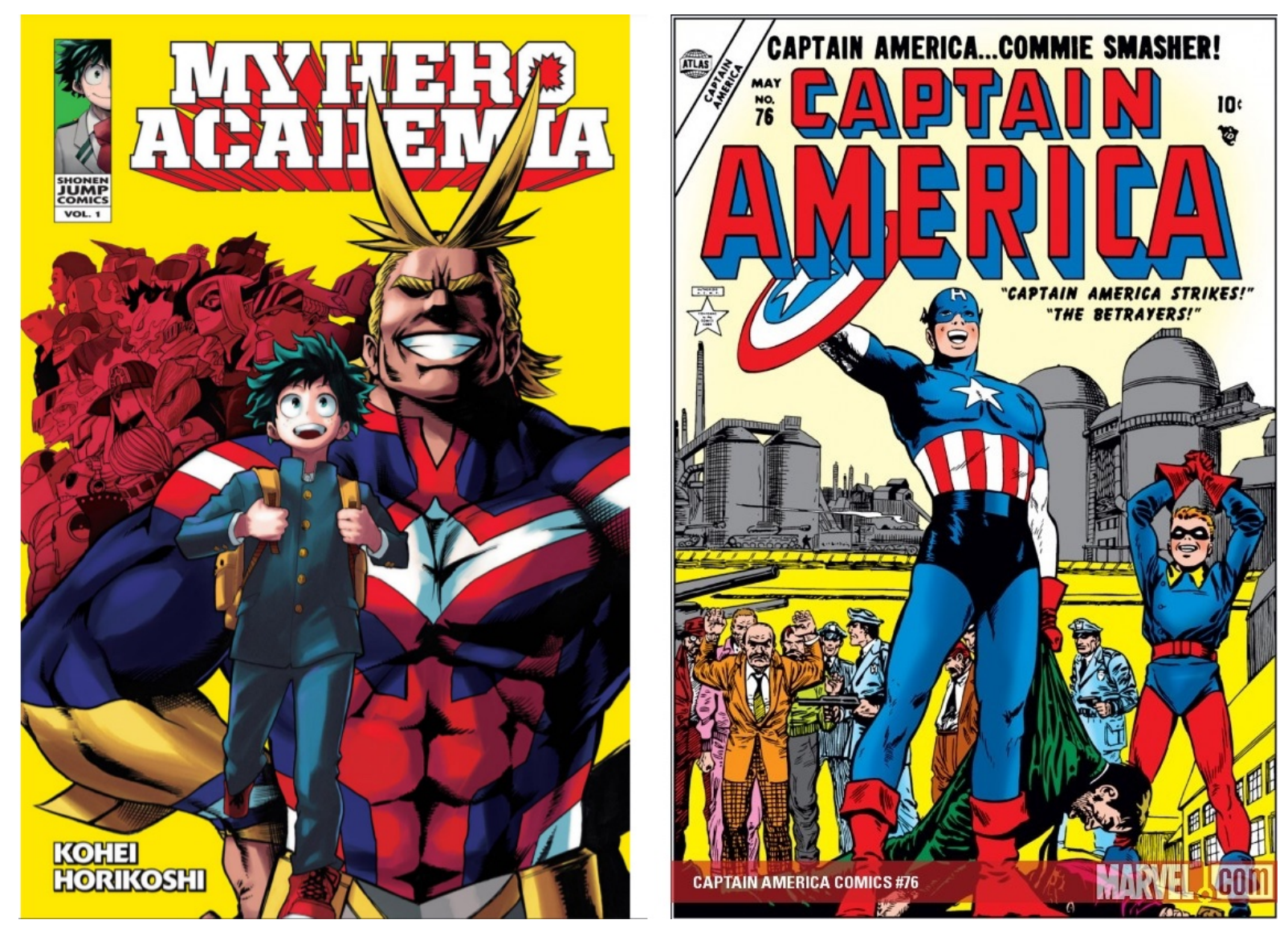

Figure 7 On the left, the cover of the first volume of My Hero Academia (2014). On the right, the cover of Captain America \#76 (1941).

However, All Might and Captain America have a lot more in common than just physical appearance. Both Steve Rogers and Toshinori Yagi (the two heroes' real names) were not privileged enough to be born with powers. In their early years, the physical appearance of both characters did not match the greatness and bravery of their hearts. Put more simply, they were two profoundly heroic men with a weak "normal" human body and thus unable to help those in need. Both characters share a physical transformation: after receiving his superpowers, Captain America becomes physically exceptional, while All Might keeps two "forms" of himself: the Hero (or Muscle) form, and the True form. In the first, he has a stereotypical hero body shape, much similar to Captain America's one and corresponding to Neal Cohn's American Visual Language definition. While speaking of possible defining features of the American visual language, Cohn identifies three "dialects" in which American drawers are used to express their art: Kirbyan (typical of the superhero comics), Barksian (especially used in cartoons) and Independent. In this particular case, both Captain America and All Might's design are attributable to the Kirbyan dialect (Cohn 139-144). The style is named after the cartoonist Jack "King" Kirby, but through time has received the influence of several artists and, of course, of Japanese manga. Its main features are physically exaggerated personages (very muscular men and extremely curvy women) and standardized facial traits such as "angular jaw, pronounced cheekbones, and distinct eyebrow muscles, especially in men" (Cohn 141). Moreover, 
Kirbyan figures often assume dramatic or dynamic poses. Going back to All Might double physical form, in his second one (the True form) he appears much shorter and thinner.

Steve Rogers received his superpowers from the super soldier serum, while Toshinori received his from the previous possessor and his mentor. Hence, they both received their abilities after demonstrating their value and obtained those powers through an external intervention. After being granted the powers, they both became a symbol of peace and stability for their country, and they took the responsibility to protect their people from villains of any kind (All Might is often referred to as "The Symbol of Peace").

Despite their considerable physical appearance and undisputed success, they are both very sensitive characters who suffer from the weight of the responsibility on their shoulders. Eventually, their story and their heroic actions prove they will never stop being humble and grateful for having the possibility to protect those in need. In fact, they avoid awards, which they feel they do not deserve. Adding to that, they are always moved by selfless motivations and never act to obtain glory or fame.

Finally, they both feel like not being personally indispensable for the sake of the symbol. They are conscious to be simply the ones who are impersonating it in that present moment, but they are well-aware that at some point they will have to pass the baton to someone else. Captain America's legacy is represented by his shield. After Steve Roger's death in the comics (2007), the shield will be passed to Bucky Barnes and then to Sam Wilson (aka Falcon), while in the Marvel Cinematic Universe it is Cap himself who entrusts Sam Wilson with the weapon. Also here, All Might will need to choose the next possessor of One for All and, as briefly mentioned above, his legacy will be entrusted to the young but brave Midoriya Izuku.

\section{All Might and UnCle SAM}

Captain America is not the only inherently American character to which All Might refers. This is particularly evident in Episode 4 of Season 1. After accepting to be All Might's successor, Midoriya starts his preparation to inherit the One for All Quirk. To that end, All Might puts the young boy through the "American Dream Plan," an intensive training that will make his mind and body strong enough to receive his idol's superpower and make use of it in the best way possible. On the day of the entrance test, All Might makes Midoriya eat a strand of his hair to transmit One for All to him and sends him to face his future. The young boy will not be able to deal with the high-level exam he has to face, but he will eventually be able to show the examiners his heroism by saving a girl's life during the test. Beaten down after the exam, Midoriya returns home thinking about what he is going to do with All Might's superpower now that he failed the entrance test. Nonetheless, in an unexpected turn of events, he receives this message:

The entrance exam [...] was not graded only in villains points! How can a hero course reject people who save others and do the right thing? [...] Rescue points! And they're given 
by a panel of judges. Midoriya Izuku: sixty points! [...] Come, young Midoriya. This is your hero academia. (Episode 4, min. 21:45)

The video message, recorded by All Might, plays while Midoriya watches the beloved idol handing out his hand in a scene much reminiscent of an Uncle Sam poster (Fig. 3). In fact, just as the character of Uncle Sam attracted American men to the army, in this specific scene All Might is recruiting Midoriya to be the next symbol of Peace and, thanks his newly acquired role as teacher at the UA, he is recruiting new students to be the next generation of Japan's superheroes.

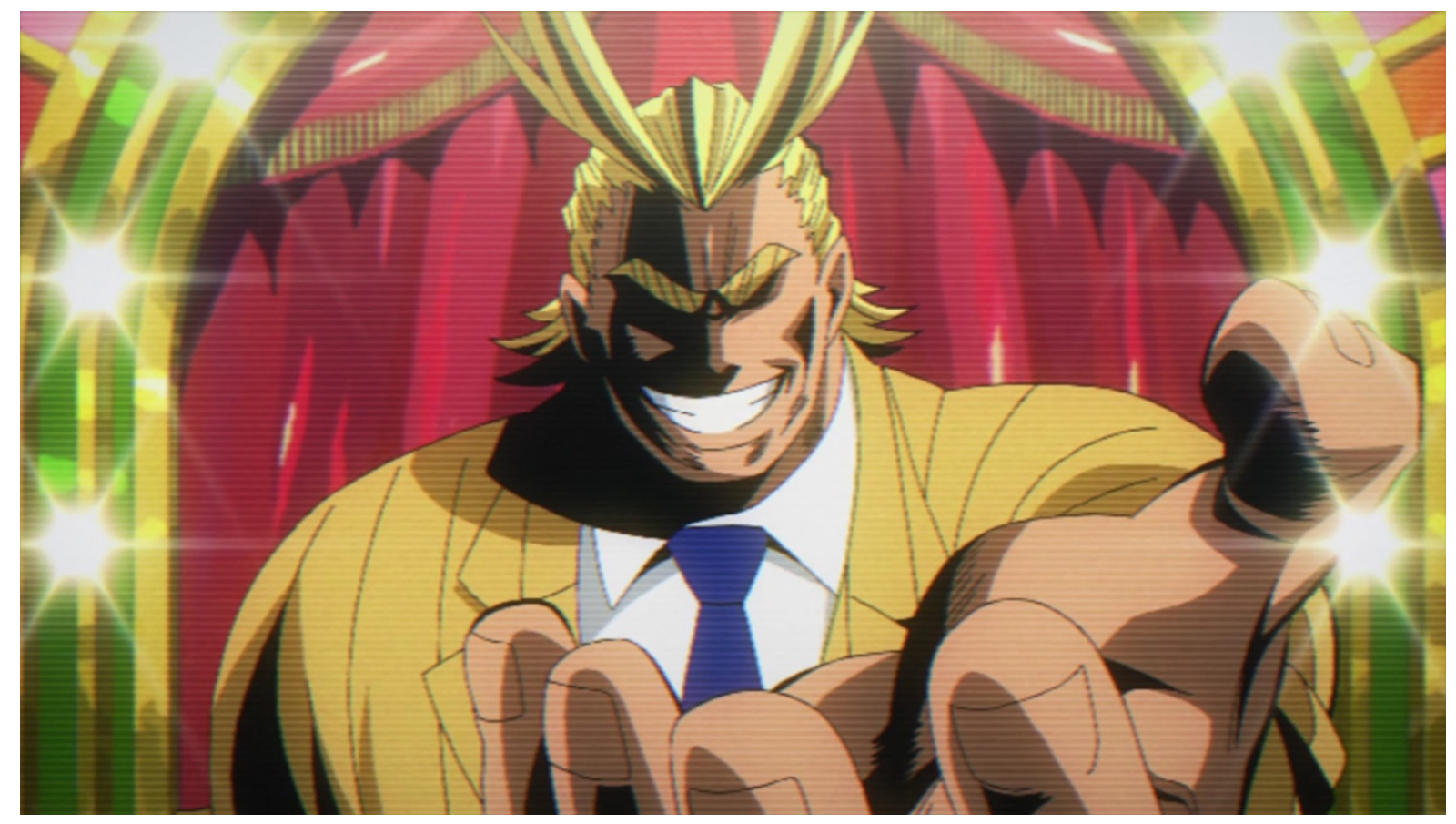

Figure 8 All Might invites Midoriya to join the U.A. Hero Academy after passing the entrance test (Season 1, Episode 4).

In Episode 11 of Season 3, All Might makes his final call for Midoriya to be the next Number One Hero. After defeating his biggest rival, a villain capable of absorbing infinite Quirks called All for One, All Might senses the last spark of power left in him expiring, leaving him exhausted and powerless in front of the cameras. Instead of taking his last shot of glory, All Might decides to use that visibility to send a message: he points a finger directly to the screen. Midoriya, who has been watching All Might's last fight from afar, sees that sign and reads the message behind it, bursting in tears. Replicating the same gesture depicted in Uncle Sam's poster, All Might is not only recruiting Midoriya as a soldier of justice but as the future leader of those who fight for that justice.

\section{All Might AND Major Glory}

A more recent American cartoon character whose resemblance with All Might cannot go unnoticed is the Cartoon Network's star Major Glory. The character has been introduced to the 
world in 1996, when the popular American network aired for the first time the Dexter's Laboratory series (1996-2003). The show deals with the adventures of a little genius boy called Dexter, a precocious scientist and inventor who spends all of his free time in a secret lab where he tries to invent high-tech items or carries out dangerous experiments. In between these vicissitudes and the protagonist's issues with his older sister Dee Dee who continuously enters the lab without his permission, the viewers also get to know some recurring side characters. Among them, Major Glory is a super-hero parody of both Captain America and Superman whose main values are justice, freedom, and patriotism. It is worth drawing a physical comparison between him and All Might, because of some additional elements that make Major Glory even more graphically similar to the Number One Hero in Japan than Captain America.

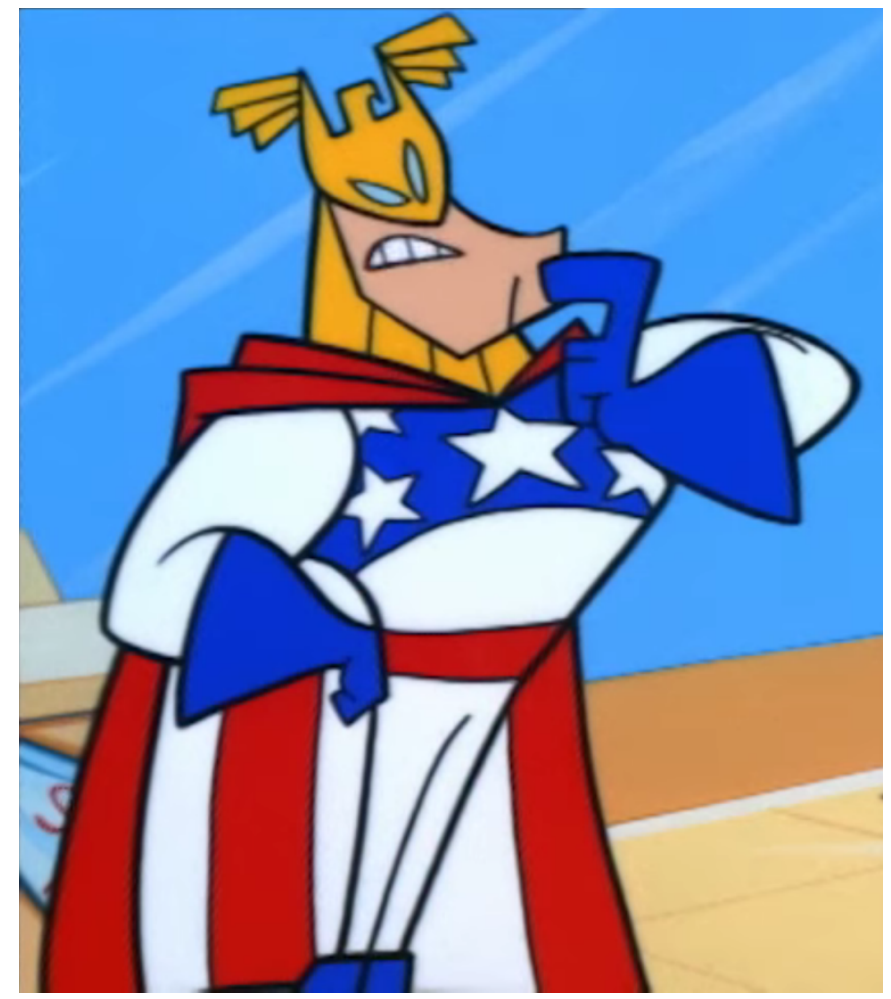

Figure 9 Major Glory (The Justice Friends [1997]).
Again, Major Glory wears a superhero suit colored in red, white and blue as a reference to the American flag. He appears like an extremely muscular, tall, and blonde man, but this time there is more. Major Glory wears a very peculiar golden helmet, which shape evokes an eagle, another very popular American symbol (Fig. 4). In fact, the whitehead eagle symbolizes the American government since the XVIII century, when the majestic animal was chosen for its exclusive belonging to the American territory and its fitness in representing values of strength, freedom and power. On the other hand, All Might does not wear any headpiece, but has a really extravagant hairstyle with two long locks of hair that stand straight above his head, forming a shape suggestive of horns or rather the wings of a golden eagle. Captain America also sports two little white wings on

his blue helmet both in the comics and in the cinematic transpositions, but they do not have the same predominant visual focus that the ones worn by Major Glory and All Might have. Major Glory and his friends were much appreciated by the audience, so much so that in 1997 Cartoon Network made a spin-off series dedicated to them titled The Justice Friends, a cartoon parody of both DC's Justice League and Marvel's Avengers. Finally, All Might and Major Glory share the same superpowers - albeit only the former's One for All powers are hereditary - as they are both extremely strong and fast. A funny contextual element that finds correspondence in this analysis is that Major Glory is supposed to be the nephew of Uncle Sam himself, who also appears as a character in The Justice Friends animated series. He is presented as the 
patriotic spirit of the USA and has trained Major Glory to become the mightiest American hero, just as All Might is training the young Midoriya in My Hero Academia.

\section{All Might AND THE USA}

At this point, it becomes clear that the character of All Might was created to process and celebrate American popular culture and to embody stereotypical American values. As Romagnoli and Pagnucci explained while discussing the origin of superheroes and their intrinsic cultural functions, superheroes are often a "personification of society's morals. Specifically, superhero stories embody American culture dichotomy between good and evil" (Romagnoli and Pagnucci 8). At the core of such phenomenon lies the fact that superheroes-as intended in contemporary mainstream popular culture and originated as being an American product preserve their original set of moral values even when inserted in a different territorial, cultural, or temporal context. In traditional US superhero comic books the line between good and evil is particularly stressed and it rarely becomes blurred. Even though this is not the case for every My Hero Academia character, it is the very definition of All Might.

In fact, throughout the series there are several morally gray characters, especially among the UA Students. For example, Bakugou bullies Midoriya but still strives to become the next Number One Hero; another of Midoriya's classmates, Mineta, is used to harass almost every female character he comes into contact with but he turns out to be indispensable in several critical situations. Nevertheless, All Might never fails to be the most powerful and fair among the heroes. He always knows what is the best way to take advantage of his Quirk to solve the situation and save everyone who is in danger, but he is also highly aware of the responsibilities that come with his powers. The dichotomy between good and evil is also stressed by the resemblance between All Might Quirk's name and the one of his fierce rival All for One. While names such as "One for All" and "All for One" might remind the audience of the renowned motto of Dumas's three musketeers, they acquire a nuanced meaning in My Hero Academia. One for All, All Might and Midoriya's Quirk, is an explicit example of their role, as superheroes, in representing good moral values. The Quirk is one for all, that is to say that it can be transmitted to everyone, and it evolves thanks to each possessor's different abilities. So, One for All is a symbol of equality, dedication, and acknowledgment of everyone's different traits and talents. On the contrary, All for One, the biggest villain on the series, has the power of stealing Quirks from others, and he uses this ability to gain more power, make people suffer and perpetrate criminal acts. So, he is a symbol of egoism, criminality, cruelty and moral corruption.

The origin of All Might's deep connection with the USA is not left unexplained. In 2018, an anime film called My Hero Academia: Two Heroes was released, its plot set between Season 2 and 3 of the series. In the film, All Might and Midoriya are leaving for a brief holiday on IIsland, an artificial island where the use of Quirks is completely free from legal boundaries and the most renowned scientists work to create technology supporting the heroes' work. On 
this occasion, All Might and Midoriya are hosted by Professor David Shield and his daughter, Melissa Shield. It is not clear if the two character's surname is a reference to Captain America's weapon, but all things considered it might be. Professor Shield is an old friend of All Might, having been All Might's wing man in the past. In addition, he designed All Might's hero suits and is one of the few to know about the secret of his power.

A few flashbacks show how the two met: when he was still a student, All Might traveled to the USA and got involved in an accident caused by a villain. After saving many people including the young Professor Shield, the two became friends and David offered to create a hero suit for All Might that would support him during his missions without getting damaged. After this episode, All Might and Professor Shield worked side by side, at least until Toshinori decided to return to Japan to become the Number One Hero he was destined to be. Despite this decision, All Might will forever cherish the time spent in America, his looks will inevitably be influenced by Professor Shield's design style and he will call his legendary attacks after some American places. In fact, throughout the series there is a number of attacks defined as "Detroit Smash," "California Smash," "Carolina Smash," and similar US-inspired names (Fig. 5). Going back to Episode 11 of Season 3 All Might will name his final fist to beat All for

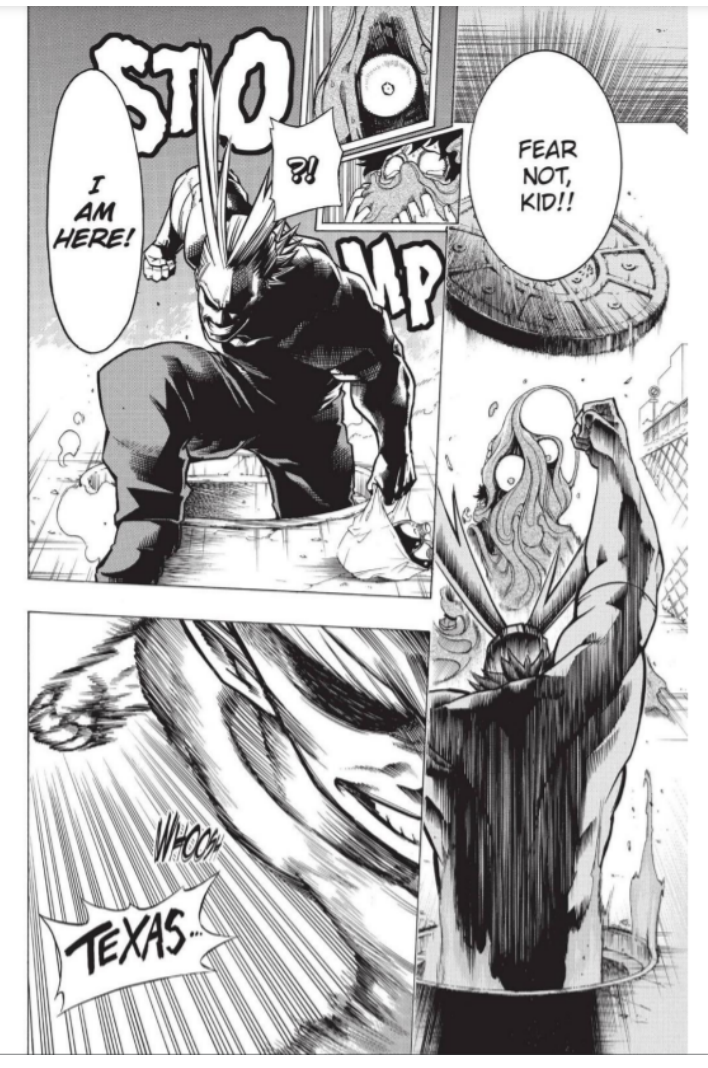

Figure 10 All Might defeats the mud monster with a “Texas Smash” (Tankōbon volume \#1, p.30). One "United States of Smash."

In 2019, an OAV episode gave even more context to All Might's connection to the USA. Though the episode is very brief, the viewers get to see All Might witnessing the defeat of his mentor, who moments before dying points at him the same way he will later point at Midoriya, saying a powerful "I'm leaving the rest to you" (Fig. 6). After this traumatic event, All Might finds out that his mentor would have wanted him to leave for the States to train until he was ready to fight the evil All for One. Respecting her last wishes, All Might leaves for the USA. All Might's love for America was probably originated by the peace he found in the States after his dramatic loss. Also, the enthusiasm for the new country and the friendship with Professor Shield helped him become stronger and ready to take his mentor's place. Put more simply, All Might lived the American Dream and this experience had the power to influence not only his style and language, but his whole story as Japan's Number One Hero. 


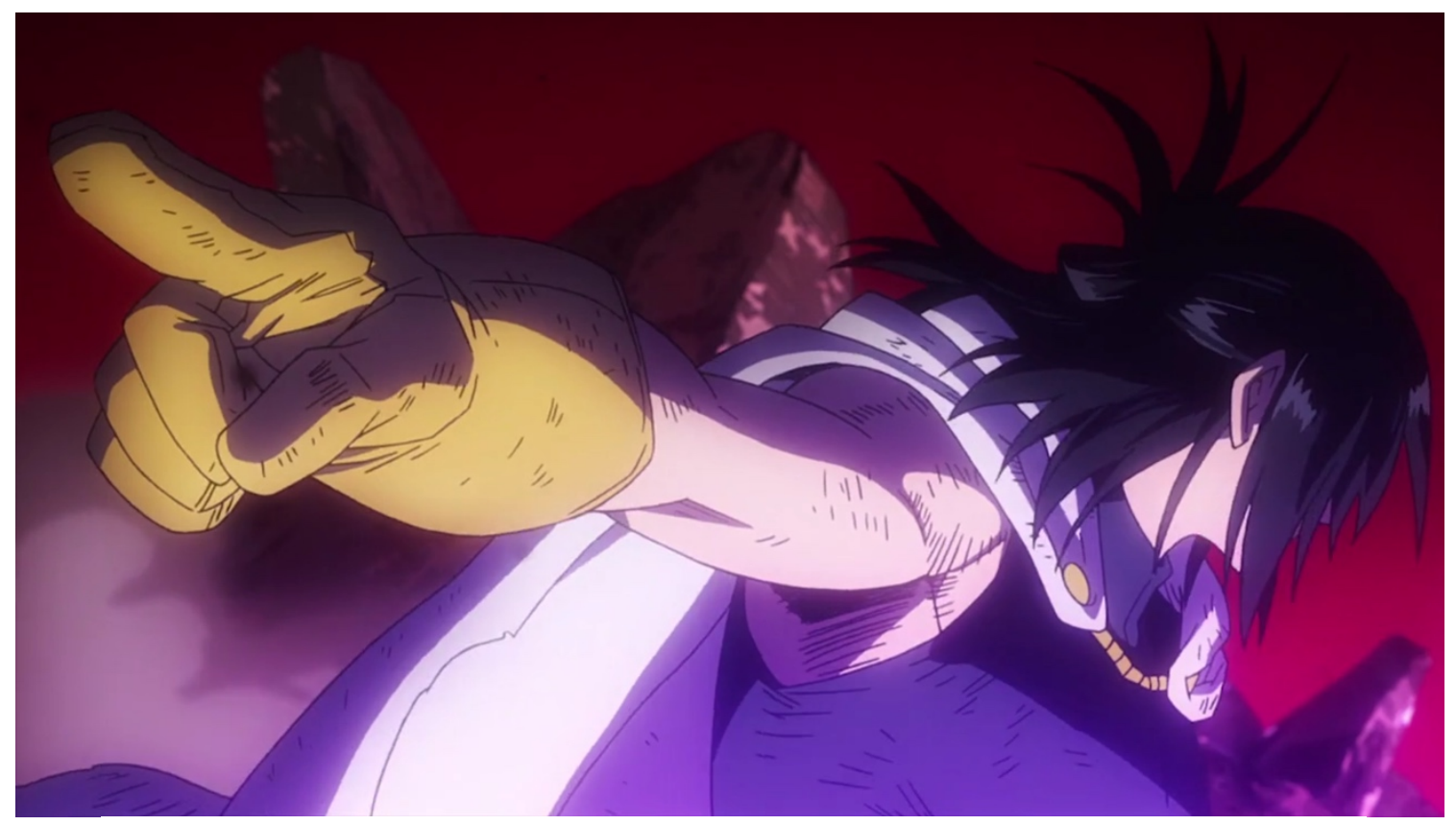

Figure 11 All Might's mentor recognizes him as her rightful successor right before losing her last battle (My Hero Academia: All Might Rising [2019]).

\section{CONCLUSIONS}

All Might's character in My Hero Academia is only one of the many examples of how American culture still has a strong influence on Japanese manga and anime productions. As Roman Rosenbaum explained while speaking of the role of manga in representing history, the graphic language of manga has, throughout the years, became a sort of lingua franca that strengthened the already existing bridge between Japan and the West world. The world's current and persistent fascination with Japanese culture in general and manga in particular is very similar to the deep Japanese infatuation for America mentioned in the introduction of this article. This creates an infinite contamination circle between Japan and the United States, where popular culture plays a lead role in keeping the respective interest and appeal alive (Otmazgin 1-25).

In the specific case of superheroes, which are-as mentioned above-an American cultural expression by definition, the contamination is exceptionally evident. Even if the archetype of the superhero is nowadays globally used by any type of media, it succeeded in preserving a lot of its original traits through space and time. There are, for examples, some common elements shared by almost every superhero: their origin is often connected with a tragedy which shaped their empathy towards others, they are usually solitary figures who are obsessed with their very ambitious goals and finally they always have some kind of weakness that help humanize them in people's eyes (Romagnoli and Pagnucci 5-18). All Might presents each one of these traits: his hard work to become the Number One Hero in Japan with the aim of being a symbol of peace for his people began when he received the One for All Quirk but increased after his beloved mentor died. Furthermore, he is presented as a solitary hero 
despite throughout the series it is explained that most famous heroes have a team of sidekicks who help them ${ }^{1}$ and, since the opening episode of the very first season, the viewers knows that All Might's most recent fight with his nemesis left him permanently damaged and his time as a superhero is running out. As all the elements considered in this analysis have proved, these correspondences are not casual and with the series still being in the making, it will be extremely interesting to observe how the character of All Might will evolve in expressing and representing more of the well-cherished American values and archetypal superhero features. In this regard, the production of Boku No Hero Academia Season 6 has already been announced. Meanwhile, the latest tankōbon volume of the manga introduced a new all-American female hero named Star and Stripes, the Number One Hero of the United States. Considering this analysis, her character's introduction will surely give new materials for further investigations on the topic.

\section{WORKS CITED}

Alt, Matt. Pure Invention: How Japan Pop Culture Conquered the World. Crown (Random House), 2020.

Berndt, Jaqueline. "Tradition of Contemporary Manga: Relating Comics to Premodern Art." SIGNs: Studies in Graphic Narratives, no. 1, 2007, pp. 33-47.

Brenner, Robin E. Understanding Manga and Anime. Libraries Unlimited, 2007.

Campbell, Joseph. The Hero with a Thousand Faces. Princeton University Press, 2004.

Cohn, Neil. The Visual Language of Comics: Introduction to the Structure and Cognition of Sequential Images. Bloomsbury, 2013.

Dittmer, Jason. Captain America and the Nationalist Superhero: Metaphors, Narratives, and Geopolitics. Temple University Press, 2012.

Drummond-Mathews, Angela. “What Boys Will Be: A Study of Shōnen Manga." Manga: An Anthology of Global and Cultural Perspectives, edited by Toni Johnson-Woods, Continuum, 2010, pp. 62-75.

Goodbrey, Daniel Merlin. "Digital comics-new tools and tropes." Studies in Comics, vol. 4, no. 1, 2013, pp. 188-197.

Irowaka, Daikichi. The Culture of the Meiji Period. Princeton University Press, 1985.

\footnotetext{
${ }^{1}$ In Season 4 a new character, Sir Nighteye, is introduced as All Might's former partner, but the two interrupted the business collaboration since, due to opposing views regarding the next possessor of One for All.
} 
Ito, Kinko. "A History of Manga in the context of Japanese culture and society." Journal of Popular Culture, vol. 38, no. 3, 2005, pp. 456-475.

Kōhei, Horikoshi. Boku No Hero Academia. \#1. Shūeisha, 2014.

McKevitt, Andrew C. "'You are not alone!': Anime and the Globalizing of America." Diplomatic History, vol. 34, no. 5, 2010, pp. 893-921.

Otmazgin, Nissim. "Introduction: Manga as 'Banal Memory'." Rewriting History in Manga, edited by Nissim Otmazgin and Rebecca Suter, Palgrave Macmillan, 2016, pp. 1-25.

Power, Natsu Onoda. God of Comics: Osamu Tezuka and the Creation of Post-World War II Manga. University Press of Mississippi, 2009.

Romagnoli Alex S., and Gian S. Pagnucci. Enter the Superheroes: American values, culture and the canon of superhero literature. The Scarecrow Press, 2013.

Rosenbaum, Roman. "Towards a Summation: How do Manga Represent History?" Manga and the Representation of Japanese History, edited by Roman Rosenbaum, Routledge, 2013, pp. 251-258.

Rosenstone, Robert A. Mirror in the Shrine: American Encounters with Meiji Japan. Harvard University Press, 1988.

Schodt, Friedrik L. Dreamland Japan: Writings on Modern Manga. Stone Bridge Press, 1996.

Schodt, Friedrik L. Manga! Manga! The world of Japanese Comics. Kodansha, 1983.

\section{Films and TV series}

My Hero Academia: Two Heroes. Directed by Kenji Nagasaki. Bones, 2018.

My Hero Academia: Heroes Rising. Directed by Kenji Nagasaki. Bones, 2019.

My Hero Academia: All Might Rising. Directed by Kenji Nagasaki. Bones, 2019.

My Hero Academia. Created by Yōsuke Kuroda. Season 1, Episodes 1-13. Bones, 2016.

My Hero Academia. Created by Yōsuke Kuroda. Season 2, Episodes 1-25. Bones, 2017.

My Hero Academia. Created by Yōsuke Kuroda. Season 3, Episodes 1-25. Bones, 2018.

My Hero Academia. Created by Yōsuke Kuroda. Season 4, Episodes 1-25. Bones, 2019. 